\title{
Physiological Response of Garlic (Allium Sativum) to Elevated Tropospheric Ozone in High Altitude Region of Western Ghats, Tamil Nadu, India
}

\section{Gayathri JawaharJothi ( $\sim$ gayathrij26821@gmail.com )}

Indian Agricultural Research Institute https://orcid.org/0000-0002-1914-8094

Boomiraj Kovilpillai

Tamil Nadu Agricultural University

Avudainayagam Subramanian

Dhanalakshmi Srinivasan Educational Institutions: Dhanalakshmi Srinivasan Group of Institutions Jayabalakrishnan Raja Mani

Tamil Nadu Agricultural University

\section{Sudhir Kumar}

Indian Agricultural Research Institute

\section{Research Article}

Keywords: Ozone, Garlic, Photosynthetic rate, Stomatal conductance, Panchagavya

Posted Date: April 5th, 2021

DOI: https://doi.org/10.21203/rs.3.rs-340795/v1

License: (9) This work is licensed under a Creative Commons Attribution 4.0 International License. Read Full License 


\section{Abstract}

A pot culture study was conducted at Horticultural Research Station, Ooty to assess the effect of ground level ozone on physiology in garlic plant and to find out the suitable remedial measures against ground level ozone. The potted soil was found to be acidic in nature with very low salt concentration, very high in organic carbon, medium in nitrogen, phosphorus and high in potassium. Elevated ozone levels (150ppb and 200ppb) had significantly reduced the garlic plant chlorophyll content, stomatal conductance, photosynthetic rate, pungency and total soluble solids. The highest chlorophyll content $\left(33.97 \mu \mathrm{molm}^{-2}\right)$ was observed under ambient ozone level $\left(T_{1}\right)$ and the lowest chlorophyll content $\left(12.68 \mu \mathrm{molm}^{-2}\right)$ was observed in elevated ozone exposure at $200 \mathrm{ppb}\left(\mathrm{T}_{3}\right)$, the highest stomatal conductance $\left(0.45 \mathrm{mmol} \mathrm{m}^{-2} \mathrm{~s}^{-}\right.$ ${ }^{1}$ ) was recorded in Ambient Ozone level + foliar spray 3\% Panchagavya $\left(T_{4}\right)$, and the lowest stomatal conductance $\left(0.11 \mathrm{mmol} \mathrm{m}^{-2} \mathrm{~s}^{-1}\right)$ was observed in elevated ozone exposure at $200 \mathrm{ppb}\left(\mathrm{T}_{3}\right)$. Since, the elevated ozone had significant reduction in photosynthetic rate in garlic, the lowest was observed $\left(0.82 \mu \mathrm{mol} \mathrm{CO} \mathrm{s}^{-1} \mathrm{~m}^{-2}\right)$ in $\mathrm{T}_{3}$ - Elevated ozone exposure at $200 \mathrm{ppb}$ and the highest photosynthetic rate $\left(3.02 \mu \mathrm{mol} \mathrm{CO} \mathrm{s}^{-1} \mathrm{~m}^{-2}\right)$ was observed in treatment $\mathrm{T}_{4}$ - Ambient Ozone level + foliar spray $3 \%$ Panchagavya after a week. When coming to quality of garlic bulbs, the highest pungency content was found in Ambient Ozone level + foliar spray $0.1 \%$ Ascorbic acid and the lowest was observed in Elevated ozone exposure at $200 \mathrm{ppb}\left(\mathrm{T}_{3}\right)$ furthermore, in observing the garlic quality where total soluble solids (TSS) showed that the treatment Ambient Ozone level + foliar spray $3 \%$ Panchagavya $\left(40.00^{\circ} \mathrm{Brix}\right)$ as highest and the treatment Elevated ozone exposure at $200 \mathrm{ppb}\left(\mathrm{T}_{3}\right)$ recorded the lowest. Thus the tropospheric ozone has detrimental impact on physiological responses, which will reduce crop growth and yield. The ozone protectants helped in scavenging the $\mathrm{O}_{3}$ from apoplast of the crops and among the ozone protectants, neem oil acted as a good ozone scavenger followed by ascorbic acid and panchagavya to improve the physiological response of garlic plant under elevated tropospheric ozone levels.

\section{Introduction}

Air pollution, the major threat to humans, crops, animals whereby the emitter source is largely by human beings. The primary air pollutants are the precursors for the formation of secondary air pollutants such as surface or tropospheric ozone $\left(\mathrm{O}_{3}\right)$. The primary air pollutants are sulfur dioxide $\left(\mathrm{SO}_{2}\right)$, carbon monoxide( $(\mathrm{CO})$, methane $\left(\mathrm{CH}_{4}\right)$, non- methane volatile organic compounds(NMVOC) and nitrogen oxides $\left(\mathrm{NO}_{\mathrm{X}}\right)$ which formed tropospheric ozone as a secondary air pollutant by the oxidation of $\mathrm{CO}, \mathrm{CH}_{4}$ or NMVOCs in the presence of $\mathrm{NO}_{x}$ (nitrogen oxides) (Unger et al., 2006) and the concentration of ozone increased due to industrialization (Grulke and Heath, 2020). Ozone is a short lived pollutant, which significantly reduced the growth, yield and productivity of crops globally (Ainsworth, 2017), when its concentration increased in the troposphere of atmosphere. The ozone enters into the plants through stomata and forming reactive oxygen species (ROS) directly by reacting with organic molecules present in the apoplast, which will cause cell damage and cell death (Ainsworth, 2017; Li et al., 2017). There will be significant decrease in soybean yield and quality, when the crop is being exposed to long term higher 
concentration of ozone (Morgan et al., 2006). According to the effect of ozone few crops has been classified so far as sensitive (Wheat, water melon, pulses, cotton, turnip, tomato, onion, soybean and lettuce), moderately sensitive (Potato, sugar beet, potato, oilseed rape, tobacco, rice, grape, broccoli and maize) and tolerant (Barley, plum and strawberry) (Emberson et al., 2009). The crops that are being exposed to higher concentration of ozone shows some common symptoms on foliar i.e., ozone injury. Acute injuries are flecking and stippling, whereas the chronic injuries are bronzing, chlorosis and premature senescence. The estimated wheat loss due to ozone is $39.7 \%, 31.8 \%$ and $26.8 \%$ in Developed Countries, Upper Middle Income Countries and Territories and Lower Middle Income Countries and Territories respectively (Mills et al., 2018)

In increasing radiative forcing, $\mathrm{O}_{3}$ as a greenhouse gas modifies water and carbon exchange between flora and atmosphere in regionally as well as globally by affecting transpiration and photosynthesis of plants (Lombardozzi et al., 2012). The potential to destruct several ways of photosynthesis happens when $\mathrm{O}_{3}$ enters the leaf via stomata, once the $\mathrm{O}_{3}$ enters the leaves, it oxidizes the cellular membrane by altering mesophyll cells thus lowering Rubisco activity and carbon fixation. This results in reducing chlorophyll content (Kulshrestha and Saxena, 2016). The regulation of photosynthesis and transpiration is modified by stomatal conductance. The direct way of affecting the plants is by changing guard cell turgor pressure and signaling pathways and indirectly by stomatal closure in case of rise in intercellular $\mathrm{CO}_{2}$ concentration (Lombardozzi et al., 2013). In few studies with respect to chronic $\mathrm{O}_{3}$ exposure there was the increase in stomatal conductance (Lombardozzi et al., 2013). Photosynthesis is directly proportional to chlorophyll content and net assimilation rate where these are the photosynthetic related parameters (Kobayakawa and Imai 2017). The decline of photosynthetic rates resulted in lowering of biomass in crops (Chen et al., 2018).

The increase in the concentration of ozone causes leaf injury, senescence, abscission, stomatal closure leading to reduction of photosynthesis, reduction of root growth, reduction of leaf growth, reduction of plant biomass and reduction of phloem translocation efficiency, which resulted in significant decreased in crop yield (Wilkinson et al., 2012). The ozone sensitivity varies across species due to species-specific biochemical, physiological and morphological traits (Li et al., 2016), stomatal conductance and to the leaf antioxidant capacity (Brosche et al., 2010; Fares et al., 2013). Increase in the concentration of ozone suppressed the photosynthetic activity and stomatal conductance, which resulted in premature leaf fall, reduction in biomass content that showed changes in physiology and growth of crops (Tetteh et al., 2015). The net photosynthesis reduction in wood plants also occurred due to elevated levels of ozone concentration ( $\mathrm{Li}$ et al., 2016). The negative effects of elevated tropospheric $\mathrm{O}_{3}$ concentration include a decreased plant growth and alter the plant metabolism that reduced the crop yield significantly (Emberson et al., 2003). Reductions in stomatal conductance(gs), net photosynthetic $\mathrm{CO}_{2}$ assimilation and carboxylation efficiency had all been associated with $\mathrm{O}_{3}$ exposure (Morgan et al., 2003). A decline in the photosynthetic rate in $\mathrm{O}_{3}$ exposed plants was associated with damage to the photosynthetic machinery that leads to reduced fixation, and increased $\mathrm{CO}_{2}$ concentration $(\mathrm{Ci})$, resulting in reduced stomatal conductance (gs) (McKee et al., 2000). 
The ozone protecting studies are also being carried out globally to reduce the ozone impact on agricultural crops and to improve crop yield. Ascorbic acid as a source of vitamin c plays an important role to reduce the ozone impact in plants such as radish (Madddison et al, 2002), Soyabean (Jiang et al., 2018), Snap bean (Burkey and Eason, 2002) and tobacco (Sanmartin et al., 2003). Application of ascorbic acid, neem oil and panchagavya were done for assessing their capability of reducing the ozone impact on garlic crop in this study. Thus the current study intended to study on physiological responses and quality of garlic to elevated different levels of ozone.

\section{Status Of Trace Gas Level At Ooty}

The study area, Ooty located in the District of Nilgiris, a fertile mountain range in Indian state of Tamil Nadu., represents a fresh, clean and pleasant environment with highly subdued human activity. Dense forests, lofty mountains, extensive tea and coffee plantation and sprawling grasslands characterize the location. The Nilgiris Hills form a part of a larger chain of mountains known as the Western Ghats along the western side of India, which is one among the eight hottest hotspots of biological diversity in the world. Due to anthropogenic activities the climate is changing drastically at Nilgiris District. Seasonal variation has been observed based on the meteorological data recorded. The maximum temperature in the summer has increased to $26^{\circ} \mathrm{C}$ (Normal $24^{\circ} \mathrm{C}$ ) and winter temperature $4^{\circ} \mathrm{C}$ (Normal $2^{\circ} \mathrm{C}$ ). Black carbon level in the summer has increased to $6000 \mathrm{ng}$ (normal level 50-100 ng) in this District. While comparing to the other regions, the carbon level is very high in this District. The measured Ozone and NOx concentrations for a period of 8 years between 2010 and March 2018 showed seasonal mean values (ppb) of $53.45 \pm 8.18,19.81 \pm 2.4,27.2 \pm 5.67$ and $42.81 \pm 5.65$ for summer, Monsoon, post monsoon and winter, respectively. A monthly maximum NOx value was observed during summer month of April (1.85 $\mathrm{ppb})$, whereas minimum during monsoon month of August (0.19 ppb). Monthly maximum $\mathrm{SO}_{2}$ observed during summer months such as March and April recorded 1.0 and $0.6 \mathrm{ppb}$, respectively and the minimum value of about $0.10 \mathrm{ppb}$ observed during November. The average CO value found to be $160.92 \pm 58.52$ $\mathrm{ppb}$. Strong diurnal and seasonal mean values of trace gases during summer are attributed mainly to the ABL dynamics, advection pathways and source types. The HYSPLIT back - trajectory analysis indicates the dominant easterly advection contributing to the seasonal high value of trace gases during summer season. Due to climate change the monsoon and pre monsoon patterns are changed. This seasonal variation directly affects the crop yield, quality, cropping pattern and the incidence of pest and diseases.

\section{Materials And Methods}

\subsection{Experimental Site and $\mathrm{O}_{3}$ measurement}

The experiment was conducted in subtropical highland climatic region of Western Ghats at $11.4{ }^{\circ} \mathrm{N}, 76.7$ ${ }^{\circ} \mathrm{E}$ at an altitude of $2520 \mathrm{~m}$ mean sea level during September to December 2018 in the experimental Woodhouse farm of Horticultural Research Station, Tamil Nadu Agricultural University, Ooty, Nilgiris District. 
The ambient ozone measurements were continuously monitored by using ozone analyzer (Thermo Fischer U.S.A Model 49 $i$ in the Fig.2) from February 2010 which is based on UV absorption. It measures the amount of ozone in the air from $0.05 \mathrm{ppb}$ concentrations up to $200 \mathrm{ppm}$. The analyzer aspirates air from a height of about $5 \mathrm{~m}$ above the ground level through Teflon tube with a flow rate of about $1 \mathrm{~L}$ per minute. The minimum detection limit of the analyzer is about $1 \mathrm{ppb}$. Calibration is done at frequent intervals using zero air and known span values. The ambient ozone concentration in the experimental site of Ooty recorded from 2010 in which minimum of $10 \mathrm{ppb}$ and maximum of $120 \mathrm{ppb}$ were recorded. The highest values of ambient $\mathrm{O}_{3}$ are found in the year 2015 and 2016 in which it peaks from 100.446 to 123 $\mathrm{ppb}$ and 100.154 to 109.199 were recorded. The unforeseen increase in the $\mathrm{O}_{3}$ concentration may expected to escalate about $150 \mathrm{ppb}$ and $200 \mathrm{ppb}$ in the years ahead. Hence this intended the authors to study with elevated $150 \mathrm{ppb}$ and $200 \mathrm{ppb}$ of $\mathrm{O}_{3}$ levels.

\subsection{Exposure design}

The electric supply was provided to connect the corona discharge through ground cable for carrying out the experiment from the Ozone generator. For the uniform distribution of ozone, which is fumigated, the axial flow fans were fixed to the open top chamber. The Garlic had been grown in prepared pots and watered regularly. The plants were maintained uniformly up to the most critical stage of garlic outside the chamber. Only during the critical stages, the crops were exposed to 150 and $200 \mathrm{ppb}$ (Elevated level of Ozone) of ozone and fumigated at the rate of 4 hours' day $^{-1}$ within the chamber.

Fig. 2. $\mathbf{O}_{3}$ Experimental design: 1) Potted garlic seedlings, 2) Garlic plants at critical stage i.e., bulb initiation stage, 3 ) Open top chamber- within which the potted plants were exposed to elevated levels of $\mathrm{O}_{3}$, 3a) Ozone Generator - fixed to the ground surface for stimulating elevated levels of ozone, 4) Ozone monitor- fixed inside the OTC for monitoring the $\mathrm{O}_{3}$ elevated levels (150ppb and 200ppb), 5)

Measurement of photosynthetic rate, stomatal conductance using Portable photosynthetic system and chlorophyll content by using chlorophyll content meter, 6) Potted garlic plants after exposure to elevated levels of $\mathrm{O}_{3}$

\subsection{Time of exposure}

Growth of a garlic plant occurs in several stages viz., clove sprouting and establishment, bulb initiation, bulb development and bulb maturation. The bulb initiation stage of garlic is considered as the important critical stage since most of the significant physiological and growth effects occurred during the later stages of crop development. So, the bulb initiation stage of garlic has been taken for elevated levels of ozone $\left(\mathrm{O}_{3}\right)$ exposures. Exposure of ozone between $40-100 \mathrm{ppb}$ may cause different injury patterns in different crops according to its sensitivity. Based on this concept the following treatments were fixed.

\subsection{Treatments details}


The potted experiment of garlic treated with two different levels of ozone (150ppb and 200ppb) under open top chambers (OTCs) with twelve treatments arranged in factorial completely randomized block design (FCRD) with three replications are as follows

$\mathrm{T}_{1}$ - Ambient ozone level,

$\mathrm{T}_{2}$ - Elevated ozone exposure at $150 \mathrm{ppb}$,

$\mathrm{T}_{3}$ - Elevated ozone exposure at $200 \mathrm{ppb}$,

$\mathrm{T}_{4}$ - Ambient ozone level + foliar spray $3 \%$ Panchagavya,

$\mathrm{T}_{5}$ - Ambient ozone level + foliar spray $3 \%$ Neem oil,

$\mathrm{T}_{6}$ - Ambient ozone level + foliar spray $0.1 \%$ Ascorbic acid,

$\mathrm{T}_{7}$ - Elevated ozone exposure at $150 \mathrm{ppb}+$ foliar spray 3\% Panchagavya,

$\mathrm{T}_{8}$ - Elevated ozone exposure at $150 \mathrm{ppb}+$ foliar spray $3 \%$ Neem oil,

$\mathrm{T}_{9}$ - Elevated ozone exposure at $150 \mathrm{ppb}+$ foliar spray $0.1 \%$ Ascorbic acid,

$\mathrm{T}_{10}$ - Elevated ozone exposure at $200 \mathrm{ppb}+$ foliar spray 3\% Panchagavya,

$T_{11}$ - Elevated ozone exposure at 200 ppb + foliar spray 3\% Neem oil,

$\mathrm{T}_{12}$ - Elevated ozone exposure at $200 \mathrm{ppb}+$ foliar spray $0.1 \%$ Ascorbic acid.

\subsection{Chlorophyll content meter}

The relative chlorophyll concentration is determined by using the instrument CCM-200 plus (chlorophyll content meter) designed by optic sciences (USA). The chlorophyll content meter readings were recorded regularly at the time of exposure of garlic to elevated levels of ozone.

\subsection{Photosynthetic rate and Stomatal conductance}

The fumigation study with elevated levels of ozone on plants in pots where the physiological responses of crop were considered as important criteria in crop growth and yield. Hence, LCpro-SD portable photosynthetic system (PPS), which designed by ADC BioScientific Ltd. was used to measure the physiological parameters i.e., photosynthetic rate and stomatal conductance. Daily readings were recorded every day at the time of exposure of crops under different concentration of ozone. The above characters were statistically analyzed by using SSPS version 16 in one-way analysis of variance (ANOVA) and the significant differences between the means were determined with Duncan's multiple range test to assess the impact of tropospheric ozone on physiological response in garlic. 


\subsection{Pungency (pyruvate analysis)}

To determine the content of naturally occurring pyruvate and carbonyl compounds, DNPH $(2,4$ dinitrophenylhydrazine) is used. The pyruvate content was determined by using a colorimetry spectrophotometer at $420 \mathrm{~nm}$ (Thermo Spectronic Genesys 20; ThermoFisher Inc., Waltham, USA) (Schwimmer and Guadagni, 1962).

\subsection{Total Soluble Solids ( ${ }^{0}$ Brix)}

Total soluble solids had been determined by using the hand-held refractometer after harvesting the bulbs. The refractometer was standardized by using distilled water. 1 to 2 drops of aliquot juice were dropped on to the prism and thus the reading were noted and washed with distilled water every time after each sample and dried with tissue paper

\section{Results}

\subsection{Physiological parameters}

\subsubsection{Chlorophyll content}

The chlorophyll content of garlic was not significantly differed initially up to four days after exposure and from fifth day onwards the significant difference was observed in chlorophyll content of garlic to elevated ozone exposure (Fig. 3). The chlorophyll content of garlic significantly reduced due to elevated ozone exposure at 150 and $200 \mathrm{ppb}$. Among the treatments, the highest chlorophyll content during $7^{\text {th }}$ day was observed in ambient ozone level $\left(T_{1}\right)\left(33.97 \mu \mathrm{mol} \mathrm{m}^{-2}\right)$ followed by $\mathrm{T}_{4}$ - Ambient Ozone level + foliar spray $3 \%$ Panchagavya $\left(32.70 \mu \mathrm{mol} \mathrm{m}^{-2}\right)$, which were on par with $\mathrm{T}_{6}$ - Ambient Ozone level + foliar spray $0.1 \%$ Ascorbic acid $\left(31.03 \mu \mathrm{mol} \mathrm{m}^{-2}\right)$ and $\mathrm{T}_{5}$ - Ambient Ozone level + foliar spray $3 \%$ Neem oil $\left(27.13 \mu \mathrm{mol} \mathrm{m} \mathrm{m}^{-2}\right)$ and the lowest chlorophyll content was recorded in $T_{3}$ - Elevated ozone exposure at $200 \mathrm{ppb}(12.68 \mu \mathrm{mol}$ $\mathrm{m}^{-2}$ ) where the second lowest value was observed in $\mathrm{T}_{11}$ - Elevated ozone exposure at $200 \mathrm{ppb}+$ foliar spray $3 \%$ Neem oil $\left(15.03 \mu \mathrm{mol} \mathrm{m}^{-2}\right)$ which were on par with $\mathrm{T}_{2}$ - Elevated ozone exposure at $150 \mathrm{ppb}$ $\left(16.93 \mu \mathrm{mol} \mathrm{m}{ }^{-2}\right)$ followed by $T_{12}$ - Elevated ozone exposure at $200 \mathrm{ppb}+$ foliar spray $0.1 \%$ Ascorbic acid $\left(17.03 \mu \mathrm{mol} \mathrm{m}^{-2}\right), \mathrm{T}_{8}$ - Elevated ozone exposure at $150 \mathrm{ppb}+$ foliar spray $3 \%$ Neem oil $\left(18.53 \mu \mathrm{mol} \mathrm{m}{ }^{-2}\right)$, $\mathrm{T}_{9}$ - Elevated ozone exposure at $150 \mathrm{ppb}+$ foliar spray $0.1 \%$ Ascorbic acid $\left(19.23 \mu \mathrm{mol} \mathrm{m}^{-2}\right)$ and $\mathrm{T}_{10}$ Elevated ozone exposure at $200 \mathrm{ppb}+$ foliar spray $3 \%$ Panchagavya $\left(19.57 \mu \mathrm{mol} \mathrm{m}{ }^{-2}\right)$ with respect to chlorophyll content in garlic.

\subsubsection{Stomatal conductance:}

The garlic stomatal conductance was significantly affected by elevated ozone exposure during critical stage (bulb initiation stage) (Table. 1) even one day after exposure, the highest stomatal conductance was observed in ambient ozone level + foliar spray $0.1 \%$ Ascorbic acid $\left(T_{6}\right)\left(0.35 \mathrm{mmol} \mathrm{m}^{-2} \mathrm{~s}^{-1}\right)$ followed 
by $T_{4}$ - Ambient Ozone level + foliar spray $3 \%$ Panchagavya $\left(0.34 \mathrm{mmol} \mathrm{m}^{-2} \mathrm{~s}^{-1}\right), \mathrm{T}_{1}$ - Ambient ozone level $\left(0.34 \mathrm{mmol} \mathrm{m}^{-2} \mathrm{~s}^{-1}\right)$ and $\mathrm{T}_{5}$ - Ambient Ozone level + foliar spray $3 \%$ Neem oil $\left(0.29 \mathrm{mmol} \mathrm{m}^{-2} \mathrm{~s}^{-1}\right)$ which were on par among themselves. Lowest stomatal conductance was observed elevated ozone exposure at $200 \mathrm{ppb}\left(\mathrm{T}_{3}\right)\left(0.14 \mathrm{mmol} \mathrm{m}^{-2} \mathrm{~s}^{-1}\right)$ followed by $\mathrm{T}_{10}$ - Elevated ozone exposure at $200 \mathrm{ppb}+$ foliar spray $3 \%$ Panchagavya $\left(0.15 \mathrm{mmol} \mathrm{m}^{-2} \mathrm{~s}^{-1}\right), \mathrm{T}_{2}$ - Elevated ozone exposure at $150 \mathrm{ppb}\left(0.16 \mathrm{mmol} \mathrm{m}^{-2} \mathrm{~s}^{-1}\right), \mathrm{T}_{11}$ Elevated ozone exposure at $200 \mathrm{ppb}+$ foliar spray $3 \%$ Neem oil $\left(0.16 \mathrm{mmol} \mathrm{m}^{-2} \mathrm{~s}^{-1}\right), \mathrm{T}_{12}$ - Elevated ozone exposure at $200 \mathrm{ppb}+$ foliar spray $0.1 \%$ Ascorbic acid $\left(0.18 \mathrm{mmol} \mathrm{m}^{-2} \mathrm{~s}^{-1}\right)$ and $\mathrm{T}_{7}$ - Elevated ozone exposure at $150 \mathrm{ppb}+$ foliar spray $3 \%$ Panchagavya $\left(0.18 \mathrm{mmol} \mathrm{m}^{-2} \mathrm{~s}^{-1}\right)$. After exposed to different levels of ozone, the ambient treatments with ozone protectants (Ascorbic acid, Neem oil and Panchagavya) recorded to be increasing at the exposure intervals and it is followed by the ambient ozone without ozone protectants. The lowest values are found in the elevated levels of ozone (200ppb and 150ppb) followed by the treatment with elevated ozone level $200 \mathrm{ppb}$ with ozone protectants and elevated ozone level 150 $\mathrm{ppb}$ with ozone protectants up to seven days.

\subsubsection{Photosynthetic rate:}

The significant reduction was observed in garlic photosynthetic rate due to elevated ozone level from the first day after exposure (Table 2.). The highest photosynthetic rate was observed in ambient Ozone level + foliar spray 3\% Panchagavya $\left(\mathrm{T}_{4}\right)\left(4.68 \mu \mathrm{mol} \mathrm{CO} 2 \mathrm{~s}^{-1} \mathrm{~m}^{-2}\right)$ followed by $\mathrm{T}_{6}$ - Ambient Ozone level + foliar spray $0.1 \%$ Ascorbic acid $\left(4.62 \mu \mathrm{mol} \mathrm{CO}_{2} \mathrm{~s}^{-1} \mathrm{~m}^{-2}\right)$, which were on par. The lowest values were observed in elevated ozone exposure at $200 \mathrm{ppb}+$ foliar spray $3 \% \mathrm{Neem}$ oil $\left(\mathrm{T}_{11}\right)\left(2.23 \mu \mathrm{mol} \mathrm{CO}_{2} \mathrm{~s}^{-1} \mathrm{~m}^{-2}\right)$ and $\mathrm{T}_{3^{-}}$ Elevated ozone exposure at $200 \mathrm{ppb}\left(2.29 \mu \mathrm{mol} \mathrm{CO}_{2} \mathrm{~s}^{-1} \mathrm{~m}^{-2}\right)$ which were on par with $\mathrm{T}_{12}$-Elevated ozone exposure at $200 \mathrm{ppb}+$ foliar spray $0.1 \%$ Ascorbic acid $\left(2.37 \mu \mathrm{mol} \mathrm{CO}_{2} \mathrm{~s}^{-1} \mathrm{~m}^{-2}\right)$ and $\mathrm{T}_{10}$ - Elevated ozone exposure at $200 \mathrm{ppb}+$ foliar spray $3 \%$ Panchagavya $\left(2.44 \mu \mathrm{mol} \mathrm{CO}_{2} \mathrm{~s}^{-1} \mathrm{~m}^{-2}\right)$. The lowest values on final day, was recorded in Elevated ozone exposure at $200 \mathrm{ppb}\left(\mathrm{T}_{3}\right)\left(0.82 \mu \mathrm{mol} \mathrm{CO}_{2} \mathrm{~s}^{-1} \mathrm{~m}^{-2}\right)$ followed by $\mathrm{T}_{2}{ }^{-}$ Elevated ozone exposure at $150 \mathrm{ppb}\left(\mathrm{T}_{2}\right)\left(1.09 \mu \mathrm{mol} \mathrm{CO}_{2} \mathrm{~s}^{-1} \mathrm{~m}^{-2}\right)$ compared to the elevated levels with ozone protectants. This showed that the ozone protectants significantly reduced the effects of ozone on garlic. Among the ozone protectants (panchagavya, neem oil and ascorbic acid) sprayed panchagavya $\left(\mathrm{T}_{10}\right.$ - Elevated ozone exposure at $200 \mathrm{ppb}+$ foliar spray 3\% Panchagavya and $\mathrm{T}_{7}$ - Elevated ozone exposure at $150 \mathrm{ppb}+$ foliar spray $3 \%$ Panchagavya) and ascorbic acid ( $\mathrm{T}_{12}$ - Elevated ozone exposure at $200 \mathrm{ppb}+$ foliar spray $0.1 \%$ Ascorbic acid and $\mathrm{T}_{9}$ - Elevated ozone exposure at $150 \mathrm{ppb}+$ foliar spray $0.1 \%$ Ascorbic acid) decreased the effects of elevated ozone on garlic than neem oil.

\subsection{Quality parameters}

\subsubsection{Pungency}

There was a significant difference among the treatments with respect to pungency content in garlic cloves due to elevated tropospheric ozone. Under the ambient condition the highest value was recorded in 
Ambient ozone level $+0.1 \%$ Ascorbic acid $\left(74.29 \mu \mathrm{mol} \mathrm{g}^{-1}\right)$ followed by Ambient ozone level $+3 \%$ Neem oil $\left(73.21 \mu \mathrm{mol} \mathrm{g}^{-1}\right)$ treatment, Ambient ozone level $+3 \%$ panchagavya $\left(72.45 \mu \mathrm{mol} \mathrm{g}^{-1}\right)$ treatment and Ambient ozone level $\left(59.73 \mu \mathrm{mol} \mathrm{g}^{-1}\right)$. As the elevated levels of tropospheric ozone causes ill effects to the crops, in garlic the treatment with Elevated ozone exposure at $200 \mathrm{ppb}\left(38.93 \mu \mathrm{mol} \mathrm{g}^{-1}\right)$ recorded the lowest value followed by the treatment Elevated ozone exposure at $150 \mathrm{ppb}\left(39.87 \mu \mathrm{mol} \mathrm{g}^{-1}\right)$.

The ozone protectants help in nullifying the effects of ozone on crop. In the garlic, the pungency in garlic bulbs after exposure with elevated levels of ozone with ozone protectants where the highest value recorded in the Elevated ozone exposure at $150 \mathrm{ppb}+0.1 \%$ Ascorbic acid $\left(59.19 \mu \mathrm{mol} \mathrm{g}^{-1}\right)$ followed by Elevated ozone exposure at $150 \mathrm{ppb}+3 \%$ panchagavya $\left(58.97 \mu \mathrm{mol} \mathrm{g}^{-1}\right)$, Elevated ozone exposure at $150 \mathrm{ppb}+3 \%$ Neem oil $\left(54.71 \mu \mathrm{mol} \mathrm{g}^{-1}\right)$. The lowest values are recorded in the treatment Elevated ozone exposure at $200 \mathrm{ppb}+3 \%$ Neem oil $\left(44.65 \mu \mathrm{mol} \mathrm{g}^{-1}\right)$ followed by the treatment Elevated ozone exposure at $200 \mathrm{ppb}+3 \%$ Panchagavya $\left(47.85 \mu \mathrm{mol} \mathrm{g}^{-1}\right)$ and Elevated ozone exposure at $200 \mathrm{ppb}+0.1 \%$ Ascorbic acid $\left(50.57 \mu \mathrm{mol} \mathrm{g}^{-1}\right)$.

\subsubsection{Total Soluble Sugars}

The total soluble sugars in the cloves of garlic showed significant difference among the treatments in view of elevated tropospheric ozone in different concentrations were shown in the Fig. 4. Among the treatments under normal conditions, the highest total soluble sugar content was recorded in Ambient Ozone level + foliar spray $3 \%$ Panchagavya $\left(40.00^{\circ}\right.$ Brix) treatment followed by Ambient Ozone level + foliar spray $3 \%$ Neem oil $\left(37.33^{\circ} \mathrm{Brix}\right)$ and Ambient Ozone level + foliar spray $0.1 \%$ Ascorbic acid $\left(37.33^{\circ} \mathrm{Brix}\right)$ treatment and the least value been recorded in Ambient ozone level ( $35^{\circ} \mathrm{Brix}$ ) treatment. Since the elevated tropospheric level had negative effect on the quality of garlic cloves the lowest value was observed in Elevated ozone exposure at $200 \mathrm{ppb}\left(28.00^{\circ} \mathrm{Brix}\right)$ treatment followed by Elevated ozone exposure at $150 \mathrm{ppb}\left(29.67^{\circ} \mathrm{Brix}\right)$ treatment.

The application of ozone protectant had reduced the ill effect of elevated tropospheric ozone on quality of garlic yield. Among the ozone protectant treatments, elevated ozone exposure at $150 \mathrm{ppb}+$ foliar spray $3 \%$ Panchagavya $\left(35.00^{\circ}\right.$ Brix) treatment had higher total soluble sugars followed by elevated ozone exposure at $150 \mathrm{ppb}+$ foliar spray $3 \%$ Neem oil $\left(34.00^{\circ} \mathrm{Brix}\right)$, elevated ozone exposure at $150 \mathrm{ppb}+$ foliar spray $0.1 \%$ Ascorbic acid $\left(31.67^{\circ} \mathrm{Brix}\right)$ treatment, elevated ozone exposure at $200 \mathrm{ppb}+$ foliar spray $3 \%$ Panchagavya $\left(31.33^{\circ} \mathrm{Brix}\right)$ treatment, Elevated ozone exposure at $200 \mathrm{ppb}+$ foliar spray $0.1 \%$ Ascorbic acid $\left(31.33^{\circ} \mathrm{Brix}\right)$ treatment and elevated ozone exposure at $200 \mathrm{ppb}+$ foliar spray $3 \%$ Neem oil $\left(30.00^{\circ}\right.$ Brix).

\section{Discussion}

The present study revealed that the physiology and quality of garlic was greatly affected by increased tropospheric ozone level. The chlorophyll content of garlic plant was significantly reduced by elevated ground level $\mathrm{O}_{3}$ of 150 and $200 \mathrm{ppb}(69.67 \%$ and $77.29 \%)$ compared to the present ozone level. The 
significant chlorophyll reduction will certainly affect the plant photosynthesis and reduce the garlic growth and yield (Gayathri et al., 2019). The chlorophyll reduction might be due to production of reactive oxidant species (ROS) in apoplast by encountering apoplastic antioxidant and killing the cell. Our results on line with Kumari et al., 2013 reported that the significant reduction was observed in total chlorophyll content by $55.9 \%$ and $50 \%$ reduction in total chlorophyll of soybean (Caregnato et al., 2013) under elevated ozone. Formation of superoxide radicles and hydrogen peroxide in leaf margin due to ozone exposure leads to trigger the injury signal by causing necrotic lesions and thus causes irreversible damage to the photosynthetic system that will lead to reduction in photosynthetic rate. In the same way, potato crop exposed under the elevated ozone resulted in chlorophyll content decline, more rapidly than the control, which triggered leaf senescence during crop growth (Donnelly et al., 2001). Similar studies on cauliflower showed that higher levels of ozone concentrations decreased chlorophyll content, which directly reduced the crop growth and yield (Sethupathi et al., 2018). The ozone will produce ROS within the cells and will evoke hypersensitive response (HR) phenomena and cause necrosis and death of cell in plants (Iriti and Faoro, 2008). The ozone induced ROS formation in cantaloupe plant reduced by the production of super oxide dismutase will scavenge the superoxide (Zhang et al., 2020). The enzymatic and non-enzymatic leaf antioxidants can't be able to maintain the intercellular redox homeostasis due to higher ROS production in the cell, which leads to oxidative damage of membrane lipids (Cargenato et al., 2010). This disintegrated membrane can cause loss of chlorophyll a and b, which reduced the photosynthetic rate and biomass accumulation of Fepagro 26 plants (Cargenato et al., 2013)

The experimental results showed that the increasing concentration of ozone reduced the stomatal conductance of leaf $(79.07 \%$ in $150 \mathrm{ppb}$ and $86.05 \%$ in $200 \mathrm{ppb}$ ) from the first day after exposure. Though it is the immediate plant adaptive mechanism to escape from the ozone injury, but the reduced stomatal conductance has direct effect on carbon dioxide exchange and transpiration rate, thereby reducing the growth and yield of garlic plant. Our results in line with findings of Noormets et al., 2010, reported that when the plants exposed to elevated ozone decreased the stomatal conductance, which reduced photosynthesis and internal $\mathrm{CO}_{2}$ concentration. Under elevated ozone concentration, reduction in the stomatal conductance and leaf area index observed in soybean (Bernacchi et al., 2006). The longterm exposure of ozone leads to loss of stomatal control, thus decreases the stomatal conductance and carbon dioxide fixation and increases the photorespiration and phosphoglycolate production (Skarby et al., 1987).

Since, the photosynthetic rate is directly influenced by elevated ozone level, significant reduction of photosynthetic rate was observed in our experiment nearly $75.06 \%$ and $81.24 \%$ in 150 and 200 ppb, which is in line with results of Vandermeiren et al., 2005 in which they observed the decreased net photosynthesis in potato crop. In palak (Lettuce) crop the reduction in the capacity of photosynthetic rate due to the leaf area reduction was observed under elevated ozone level compared to ambient ozone level (Kumari et al., 2013). The reduction in photosynthetic rate and stomatal conductance were observed along with extensive visible leaf damage under ozone exposure (Sanmartin et al., 2003). Similarly, the greater accumulation of ROS in leaf is the result of reaction between ozone with symplastic and 
apoplastic cell components (Cho et al., 2011), caused an oxidative damage to photosynthetic membrane and death of photosynthetic mesophyll cells that takes place due to ozone effects which works through excess ROS production, so reduction in rate of photosynthesis and chlorophyll loss both occurs in sequence (Chen et al., 2005). Membrane integrity of the chloroplasts affected by ozone, initially but afterwards it affects mesophyll cells which affects photosynthesis in this whole process, so effect on mesophyll cells bring both reductions in chlorophyll content which consequently leads to reduction in photosynthesis rate (Tiwari et al., 2018). Excess ozone will affect the gas exchange (Black et al., 2007) which bring both effects of reduced photosynthesis and chlorophyll content. When the $\mathrm{C}_{3}$ plants exposed to $100 \mathrm{ppb}$ of ozone, decreased rate of photosynthesis and stomatal conductance and increased rate of respiration were observed (Ainsworth et al., 2008; Feng et al., 2008).

The quality parameter such as pungency (33.25\%-150ppb and 34.82\%-200ppb) and TSS (15.23\%-150ppb and $20 \%-200 \mathrm{ppb}$ ) had been reduced by increased ozone concentration. This reduction in quality could be due to reduction in photosynthetic rate in one hand where most of the available photosynthate diverted for antioxidant production metabolisms for sustaining the plant under elevated ozone concentration. Similar results were observed by Booker et al., 2009 stated that the elevated $\mathrm{O}_{3}$ not only reduce the yield and also alters the quality of crops. Borberg et al., 2015 and Frei et al., 2015 revealed that the starch content and grain size were decreased in wheat and rice under elevated ozone. Recently similar results were observed in soybean by Broberg et al., 2020 stating that the $200 \mathrm{~kg} / \mathrm{ha}$ of seed protein was found to be decreased due to current ozone levels. The quality reduction is mainly due to more allocation of carbohydrates for maintenance and repair process by producing more secondary metabolites (Biswas et al., 2008), which reduced the availability of photosynthate for economic parts and suppressed the quality improvement in crops.

The production of ascorbic acid by plants is a defense mechanism to alleviate ROS and allied stress. Exogenous application of ascorbic acid stimulates growth and photosynthesis of wheat (Malik and Asraf, 2012). In many crops external application of ascorbate plays key role as antioxidant. Some reports are available which shows that the external applications of ascorbate in plants reduced the foliar injury and improve photosynthetic rate against ozone impact ascorbate in apoplast can protect plants from ozone damage (Wang et al., 2015; Dai et al., 2020). Hence, applying ascorbic acid, neem oil and panchagavya were performed for reducing the ozone impact on garlic crop in our study where nearly $10-20 \%$ amelioration taken place against the effects of elevated levels of $\mathrm{O}_{3}$. The ascorbate synthesis as byproduct of photosynthesis and an important component in photonic energy dissipation mechanisms is also important detoxification function (Mehler peroxidase reaction) in chloroplast (Asada, 2006). Ascorbate in apoplast can protect plants from ozone damage (Plochl et al, 2000) by acting as a substrate for ROS scavenging enzymatic reactions (Chen and Gallie, 2005). The plant species which produce increased level of ascorbate exhibits resistance to ozone exposure (Feng et al., 2010). Yendrek et al., 2015 revealed that in garden pea showed greater quantity of phenolic compounds, foliar glutathione and enhanced NADH dehydrogenase transcript abundance, which attributed the plants are highly resistant to ozone damage. The external applications of ascorbate in plants reduced the foliar injury and improve 
photosynthetic rate against ozone impact (Maddison et al., 2002). Similarly, Venkatesh and Park, 2014 stated that ascorbate plays a major role in cellular ROS scavenging activity and also influence many stress responsive enzyme activities through synergetic action with the other antioxidant such as glutathione and a-tocopherol to protect cell from oxidative damage.

\section{Conclusion}

Hence the present study revealed that the elevated tropospheric ozone showed deleterious effects on the physiology and quality of garlic which would regulate the growth and yield. With the above observations we conclude that the elevated tropospheric ozone with increased concentration showed detrimental effects on physiological responses (chlorophyll content, photosynthetic rate and stomatal conductance) and quality parameters such as pungency and total soluble sugars on garlic crop, nevertheless ozone protectants such as panchagavya, neem oil and ascorbic acid stimulated the plant defense mechanism, which generated the counteracting mechanism in protecting the plant tissues against $\mathrm{O}_{3}$ toxicity. Among the ozone protectants, neem oil performed well followed by ascorbic acid and panchagavya. Though the tropospheric ozone is short lived air pollutant, which have been identified as one of the potent greenhouse gas recently by Intergovernmental Panel on Climate Change (IPCC), the future research may be focused to study the tropospheric ozone impact studies on different food crops in detail and identify the better ozone protectants and its mode of action for nullifying the negative impact of tropospheric ozone to sustain agriculture production and food security for ever increasing population with less land and limited water resources under changing climate.

\section{Declarations}

\section{Acknowledgement}

We thank ISRO-GBP Climate Change Observatory, Ooty, Department of Environmental Science, Tamil Nadu Agricultural University, Coimbatore for providing laboratory facilities and Horticultural Research Station, Woodhouse Farm, Ooty who facilitated and supported the smooth conduct of the field experiment. 


\begin{tabular}{|c|c|}
\hline $\begin{array}{l}\text { Ethical } \\
\text { Approval }\end{array}$ & Not applicable \\
\hline $\begin{array}{l}\text { Consent to } \\
\text { Participate }\end{array}$ & Not applicable \\
\hline $\begin{array}{l}\text { Consent to } \\
\text { Publish }\end{array}$ & Not applicable \\
\hline \multirow[t]{6}{*}{$\begin{array}{l}\text { Authors } \\
\text { Contributions }\end{array}$} & $\begin{array}{l}\text { 1. Gayathri JawaharJothi as the corresponding author, conducted the field work, } \\
\text { sample collection, analysis and final preparation of thesis and submitted }\end{array}$ \\
\hline & $\begin{array}{l}\text { 2. Boomiraj Kovilpillai developed and designed the methodology and performed } \\
\text { entire correction of the work and finally shaped it. }\end{array}$ \\
\hline & 3. Avudainayagam Subramanian was the chairman of the advisory committee \\
\hline & 4. Jayabalakrishnan Raja Mani analyzed the air quality of the research location \\
\hline & 5. Sudhir Kumar worked in correcting the manuscript \\
\hline & All authors read and approved the final manuscript \\
\hline Funding & No funding have provided for this research work \\
\hline $\begin{array}{l}\text { Competing } \\
\text { Interests }\end{array}$ & The authors declare that they have no competing interests \\
\hline \multirow{3}{*}{$\begin{array}{l}\text { Availability } \\
\text { of data and } \\
\text { materials }\end{array}$} & $\begin{array}{l}\text { 1. The datasets analyzed during this current study are available from the } \\
\text { corresponding author and it is a part of my post graduate thesis. }\end{array}$ \\
\hline & $\begin{array}{l}\text { 2. The growth and yield of the garlic crop due to elevated levels of } \mathrm{O}_{3} \text { have added to } \\
\text { the reference and its citation is "Gayathri } \mathrm{J} \text {, Boomiraj } \mathrm{K} \text {, Avudainayagam } \mathrm{S} \text {, } \\
\text { Maheswari M, Chandrasekhar CN, Karthikeyan } \mathrm{S} \text {. Impact of tropospheric ozone on } \\
\text { growth and yield of garlic in high altitude region of Western Ghats. Int J Chem Stud } \\
2019 ; 7(3): 3099-3101 \text { ". }\end{array}$ \\
\hline & $\begin{array}{l}\text { 3. The ambient } \mathrm{O}_{3} \text { data have retrieved from the project ISRO-GBP (ATCTM) which } \\
\text { was an unpublished data. The project undergoing in our institution. }\end{array}$ \\
\hline
\end{tabular}

\section{References}

1. Ainsworth, E.A. (2016) Understanding and improving global crop response to ozone pollution. The Plant Journal. 90(5), 886-897.

2. Ainsworth, E.A., Rogers, A. and Leakey, A.D.B. (2008) Targets for crop biotechnology in a future highCO2 and high-03 world. Plant Physiol. 147, 13-19

3. Asada K. (2006) Production and scavenging of reactive oxygen species in chloroplasts and their functions. Plant Physiol 141:391-396

4. Bernacchi, C.J., et al., (2006) Hourly and seasonal variation in photosynthesis and stomatal conductance of soybean grown at future $\mathrm{CO}_{2}$ and ozone concentrations for 3 years under fully openair field conditions. Plant, Cell \& Environment. 29(11), 2077-2090. 
5. Biswas, D.K., Xu, H., Li, Y.G., Sun, J.Z., Wang, X.Z., Han, X.G., Jiang, G.M., (2007) Genotypic differences in leaf biochemical, physiological and growth responses to ozone in 20 winter wheat cultivars released over the past 60 years. Glob. Change Biol. 14, 46-59. http://dx.doi.org/10.1111/j.1365-2486.2007.01477.x.asa

6. Black, V. J., Stewart, C. A., Roberts, J. A., \& Black, C. R. (2007). Ozone affects gas exchange, growth and reproductive development in Brassica campestris (Wisconsin Fast Plants). New Phytologist, 176(1), 150-163.

7. Booker, F., Muntifering, R., McGrath, M., Burkey, K., Decoteau, D., Fiscus, E., Manning, W., Krupa, S., Chappelka, A. and Grantz, D. (2009) The ozone component of global change: potential effects on agricultural and horticultural plant yield, product quality and interactions with invasive species. J. Integr. Plant Biol. 51, 337-351.

8. Broberg, M.C., Feng, Z.Z., Xin, Y. and Pleijel, H. (2014) Ozone effects on wheat grain quality - a summary. Environ. Pollut. 197, 203-213.

9. Broberg, MC, Daun S, Pleijel H. (2020) Ozone induced loss of seed protein accumulation is larger in soybean than in wheat and rice. Agronomy 10, 357. (doi:10.3390/agronomy10030357)

10. Brosché M, Merilo E, Mayer F, Pechter P, Puzõrjova I, Brader G, Kangasjärvi J, Kollist H. (2010) Natural variation in ozone sensitivity among Arabidopsis thaliana accessions and its relation to stomatal conductance. Plant, Cell and Environment. 33:914-925.

11. Burkey, K.O.; Eason, G. (2002) Ozone tolerance in snap bean is associated with elevated ascorbic acid in the leaf apoplast. Physiol. Plant. 114, 387-394.

12. Caregnato, F.F., Bortolin, R.C., Divan Junior, A.M. and Moreira, J.C.F. (2013). Exposure to elevated ozone levels differentially affects the antioxidant capacity and the redox homeostasis of two subtropical Phaseolus vulgaris L. varieties. Chemosphere 93, 320-330.

13. Caregnato, F.F., Clebsch, C.C., Rocha, R.F., Feistauer, L.B.H., Oliveira, P.L., Divan, A.D., Moreira, J.C.F., (2010). Ozone exposure differentially affects oxidative stress parameters in distinct Phaseolus vulgaris L. varieties. J. Plant Interact. 5, 111-115.

14. Chen Z, Gallie DR (2005) Increasing tolerance to ozone by elevating foliar ascorbic acid confers greater protection against ozone than increasing avoidance. Plant Physiol. 138:1673-1689

15. Chen, Z., Cao, J., Yu, H., \& Shang, H. (2018). Effects of elevated ozone levels on photosynthesis, biomass and non-structural carbohydrates of Phoebe bournei and Phoebe zhennan in subtropical China. Frontiers in Plant Science, 9, 1764.

16. Cho K, Tiwari S, Agrawal SB, Torres NL, et al., (2011) Tropospheric ozone and plants: absorption, responses and consequences. Rev Environ Contam Toxicol 212:61-111

17. Dai, L., Kobayashi, K., Nouchi, I., Masutomi, Y., \& Feng, Z. (2020). Quantifying determinants of ozone detoxification by apoplastic ascorbate in peach (Prunus persica) leaves using a model of ozone transport and reaction. Global change biology, 26(5), 3147-3162.

18. Donnelly, A., et al., (2001) Does elevated $\mathrm{CO}_{2}$ ameliorate the impact of $\mathrm{O}_{3}$ on chlorophyll content and photosynthesis in potato (Solanum tuberosum)?. Physiologia plantarum. 111(4), 501-511. 
19. Emberson, L., Ashmore, M., Murray, F., (2003) Air pollution impacts on crops and forests: a global assessment. Imperial College Press.

20. Emberson, L.D., et al., (2009) A comparison of North American and Asian exposure-response data for ozone effects on crop yields. Atmospheric Environment. 43(12), 1945-1953.

21. Fares A, Vargas R, Detto M, Goldstein AH, Karlik J, Paoletti E, Vitale M. (2013) Tropospheric ozone reduces carbon assimilation in trees: estimates from analysis of continuous flux measurements. Global Change Biology. 19:2427-2443. [PubMed: 23589473]

22. Feng Z, Pang J, Nouchi I, Kobayashi K, Yamakawa T, Zhu J (2010) Apoplastic ascorbate contributes to the differential ozone sensitivity in two varieties of winter wheat under fully open-air field conditions. Environ. Pollut. 158:3539-3545

23. Feng, Z.Z., Kobayashi, K. and Ainsworth, E.A. (2008) Impact of elevated ozone concentration on growth, physiology, and yield of wheat (Triticum aestivum L.): a meta-analysis. Glob. Chang. Biol. 14, 2696-2708.

24. Frei, M. (2015) Breeding of ozone resistant rice: relevance, approaches and challenges. Environ. Pollut. 197, 144-155.

25. Gayathri, J., Boomiraj, K., Avudainayagam, S., Maheswari, M., Chandrasekhar, C. N., \& Karthikeyan, S. (2019) Impact of tropospheric ozone on growth and yield of garlic in high altitude region of Western Ghats. IJCS, 7(3), 3099-3101.

26. Grulke, N.E. and Heath, R.L. (2019) Ozone effects on plants in natural ecosystems. Plant Biol. 22(S1),12-37. (doi:10.1111/plb.12971)

27. Iriti, M., \& Faoro, F. (2008). Oxidative stress, the paradigm of ozone toxicity in plants and animals. Water, Air, and Soil Pollution, 187(1), 285-301.

28. Jiang, L.; Feng, Z.; Dai, L.; Shang, B.; Paoletti, E. (2017) Large variability in ambient ozone sensitivity across 19 ethylenediurea-treated Chinese cultivars of soybean is driven by total ascorbate. J. Environ. Sci., 64, 10-22.

29. Kobayakawa, H., \& Imai, K. (2016) Exogenous ascorbic acid scarcely ameliorates inhibition of photosynthesis in rice leaves by 03. Plant Production Science, 20(1), 83-89.

30. Kulshrestha, U., \& Saxena, P. (Eds.). (2016). Plant responses to air pollution. Springer.

31. Kumari, S., et al., (2013) Impact of elevated $\mathrm{CO}_{2}$ and elevated $\mathrm{O}_{3}$ on Beta vulgaris $\mathrm{L}$.: pigments, metabolites, antioxidants, growth and yield. Environmental pollution. 174, 279-288.

32. Li P, Calatayud V, Gao F, Uddling J, Feng Z. (2016) Differences in ozone sensitivity among woody species are related to grleaf morphology and antioxidant levels. Tree Physiol. Sep;36(9):1105-16. doi: 10.1093/treephys/tpw042. Epub 2016 May 22. PMID: 27217527

33. Li S, Harley PC, Niinemets Ü. (2017) Ozone-induced foliar damage and release of stress volatiles is highly dependent on stomatal openness and priming by low-level ozone exposure in Phaseolus vulgaris. Plant, Cell and Environment. 40:1984-2003. 
34. Lombardozzi, D., Levis, S., Bonan, G., \& Sparks, J. P. (2012). Predicting photosynthesis and transpiration responses to ozone: decoupling modeled photosynthesis and stomatal conductance. Biogeosciences, 9(8), 3113-3130.

35. Lombardozzi, D., Sparks, J. P., \& Bonan, G. (2013) Integrating $\mathrm{O}_{3}$ influences on terrestrial processes: photosynthetic and stomatal response data available for regional and global modeling. Biogeosciences, 10(11), 6815.

36. Maddison, J.; Lyons, T.; Plöchl, M.; Barnes, J. (2002) Hydroponically cultivated radish fed Lgalactono-1,4-lactone exhibit increased tolerance to ozone. Planta, 214, 383-391.

37. Malik, S., \& Ashraf, M. (2012). Exogenous application of ascorbic acid stimulates growth and photosynthesis of wheat (Triticum aestivum L.) under drought. Soil \& Environment, 31(1).

38. McKee, I.F., et al., (2008) Elevated concentrations of atmospheric $\mathrm{CO}_{2}$ protect against and compensate for $\mathrm{O}_{3}$ damage to photosynthetic tissues of field-grown wheat. New Phytologist. 146(3), 427-435.

39. Mills, Gina; Sharps, Katrina; Simpson, David; et al., (2018) Ozone pollution will compromise efforts to increase global wheat production. Global Change Biology, 24 (8). 3560-3574, https://doi.org/10.1111/gcb.14157

40. Morgan, P.B., Ainsworth, E.A., Long, S.P., (2003) How does elevated ozone impact soybean? A metaanalysis of photosynthesis, growth and yield. Plant, Cell \& Environment. 26(8), 1317-1328.

41. Morgan, P.B., et al., (2006) Season-long elevation of ozone concentration to projected 2050 levels under fully open-air conditions substantially decreases the growth and production of soybean. New Phytologist. 170(2), 333-343.

42. Noormets, A., et al., (2010) Elevated $\mathrm{CO} 2$ response of photosynthesis depends on ozone concentration in aspen. Environmental Pollution 158(4), 992-999.

43. Plöchl M, Lyons T, Ollerenshaw J, Barnes J (2000) Simulating ozone detoxification in the leaf apoplast through the direct reaction with ascorbate. Planta. 210:454-467

44. Sanmartin, M.; Drogoudi, P.D.; Lyons, T.; Pateraki, I.; Barnes, J.; Kanellis, A.K. (2003) Over-expression of ascorbate oxidase in the apoplast of transgenic tobacco results in altered ascorbate and glutathione redox states and increased sensitivity to ozone. Planta 2003, 216, 918-928.

45. Schwimmer, S., \& Guadagni, D. G. (1962) Relation between olfactory threshold concentration and pyruvic acid content of onion juice. Journal of food Science. 27(1), 94-97.

46. Sethupathi, N., Boomiraj, K., Sritharan, N., (2018) Effect of Elevated Ozone on Plant Nutrients, Chlorophyll Content and Antioxidant Enzymes in Cauliflower (Brassica oleracea var. botrytis L.). Madras Agricultural Journal. 105(march (1-3), 1.

47. Skärby, L., Troeng, E., Boström, C.A., 1987. Ozone uptake and effects on transpiration, net photosynthesis, and dark respiration in Scots pine. Forest Science. 33(3), 801-808.

48. Tetteh, R., et al., (2015) Effects of ozone on growth, net photosynthesis and yield of two African varieties of Vigna unguiculata. Environmental Pollution. 196, 230-238. 
49. Tiwari, S., \& Agrawal, M. (2018). Effect of ozone on physiological and biochemical processes of plants. In Tropospheric Ozone and its Impacts on Crop Plants (pp. 65-113). Springer, Cham.

50. Unger, N., et al., (2006) Influences of man-made emissions and climate changes on tropospheric ozone, methane, and sulfate at 2030 from a broad range of possible futures. Journal of Geophysical Research: Atmospheres. 111(D12).

51. Vandermeiren, K., et al., (2005) Impact of rising tropospheric ozone on potato: effects on photosynthesis, growth, productivity and yield quality. Plant, Cell \& Environment. 28(8), 982-996.

52. Venkatesh, J. and Park, S.W. (2014) Role of L-ascorbate in alleviating abiotic stresses in crop plants. Botanical Studies. 2014, 55:38

53. Wang, L., Pang, J., Feng, Z., Zhu, J., \& Kobayashi, K. (2015). Diurnal variation of apoplastic ascorbate in winter wheat leaves in relation to ozone detoxification. Environmental Pollution, 207, 413-419.

54. Wilkinson., et al., (2012) How is ozone pollution reducing our food supply?. Journal of Exp. Bot. 63(2), 527-536.

55. Yendrek, C.R., Koester, R.P. and Ainsworth, E.A. (2015) A comparative analysis of transcriptomic, biochemical and physiological responses to elevated ozone identifies species-specific mechanisms of resilience in legume crops. J. Exp. Bot. 66, 7101-711.

56. Zhang, H., Zhang, X., Dong, C., Zhang, N., Ban, Z., Li, L., ... \& Chen, C. (2020). Effects of ozone treatment on SOD activity and genes in postharvest cantaloupe. RSC Advances, 10(30), 1745217460.

\section{Tables}

Table 1. Influence of tropospheric ozone on stomatal conductance of garlic 


\begin{tabular}{|c|c|c|c|c|c|}
\hline Treatments & DBE & $\begin{array}{l}1^{\text {st }} \\
\text { DAE }\end{array}$ & $\begin{array}{l}3^{\text {rd }} \\
\text { DAE }\end{array}$ & $\begin{array}{l}5^{\text {th }} \\
\text { DAE }\end{array}$ & $\begin{array}{l}7^{\text {th }} \\
\text { DAE }\end{array}$ \\
\hline $\mathrm{T}_{1}-$ Ambient ozone level & $\begin{array}{l}0.43 \pm \\
0.055^{\text {dcba }}\end{array}$ & $\begin{array}{l}0.34 \pm \\
0.049^{a}\end{array}$ & $\begin{array}{l}0.34 \pm \\
0.044^{\mathrm{a}}\end{array}$ & $\begin{array}{l}0.35 \pm \\
0.029^{a}\end{array}$ & $\begin{array}{l}0.35 \pm \\
0.028^{a}\end{array}$ \\
\hline $\mathrm{T}_{2}-$ Elevated ozone exposure at $150 \mathrm{ppb}$ & $\begin{array}{l}0.41 \pm \\
0.032^{\mathrm{dcba}}\end{array}$ & $\begin{array}{l}0.16 \pm \\
0.026^{b}\end{array}$ & $\begin{array}{l}0.09 \pm \\
0.023^{c b}\end{array}$ & $\begin{array}{l}0.13 \pm \\
0.031^{b}\end{array}$ & $\begin{array}{l}0.09 \pm \\
0.020^{b}\end{array}$ \\
\hline $\mathrm{T}_{3}$ - Elevated ozone exposure at $200 \mathrm{ppb}$ & $\begin{array}{l}0.31 \pm \\
0.041^{\mathrm{dc}}\end{array}$ & $\begin{array}{l}0.14 \pm \\
0.028^{b}\end{array}$ & $\begin{array}{l}0.02 \pm \\
0.003^{c}\end{array}$ & $\begin{array}{l}0.09 \pm \\
0.020^{b}\end{array}$ & $\begin{array}{l}0.06 \pm \\
0.015^{b}\end{array}$ \\
\hline $\begin{array}{l}\mathrm{T}_{4}-\text { Ambient Ozone level + foliar spray } 3 \% \\
\text { Panchagavya }\end{array}$ & $\begin{array}{l}0.33 \pm \\
0.086^{\mathrm{dcb}}\end{array}$ & $\begin{array}{l}0.34 \pm \\
0.026^{\mathrm{a}}\end{array}$ & $\begin{array}{l}0.35 \pm \\
0.034^{\mathrm{a}}\end{array}$ & $\begin{array}{l}0.37 \pm \\
0.023^{\mathrm{a}}\end{array}$ & $\begin{array}{l}0.41 \pm \\
0.019^{\mathrm{a}}\end{array}$ \\
\hline $\begin{array}{l}T_{5}-\text { Ambient Ozone level + foliar spray } 3 \% \\
\text { Neem oil }\end{array}$ & $\begin{array}{l}0.27 \pm \\
0.035^{d}\end{array}$ & $\begin{array}{l}0.29 \pm \\
0.022^{\mathrm{a}}\end{array}$ & $\begin{array}{l}0.36 \pm \\
0.027^{a}\end{array}$ & $\begin{array}{l}0.38 \pm \\
0.039^{a}\end{array}$ & $\begin{array}{l}0.42 \pm \\
0.038^{\mathrm{a}}\end{array}$ \\
\hline $\begin{array}{l}\mathrm{T}_{6}-\text { Ambient Ozone level + foliar spray } 0.1 \% \\
\text { Ascorbic acid }\end{array}$ & $\begin{array}{l}0.33 \pm \\
0.022^{\mathrm{dcb}}\end{array}$ & $\begin{array}{l}0.35 \pm \\
0.023^{a}\end{array}$ & $\begin{array}{l}0.35 \pm \\
0.034^{\mathrm{a}}\end{array}$ & $\begin{array}{l}0.41 \pm \\
0.055^{\mathrm{a}}\end{array}$ & $\begin{array}{l}0.42 \pm \\
0.069^{a}\end{array}$ \\
\hline $\begin{array}{l}\mathrm{T}_{7}-\text { Elevated ozone exposure at } 150 \mathrm{ppb}+ \\
\text { foliar spray } 3 \% \text { Panchagavya }\end{array}$ & $\begin{array}{l}0.35 \pm \\
0.058^{d c b}\end{array}$ & $\begin{array}{l}0.18 \pm \\
0.032^{b}\end{array}$ & $\begin{array}{l}0.14 \pm \\
0.044^{b}\end{array}$ & $\begin{array}{l}0.16 \pm \\
0.044^{b}\end{array}$ & $\begin{array}{l}0.09 \pm \\
0.015^{b}\end{array}$ \\
\hline $\begin{array}{l}\mathrm{T}_{8} \text { - Elevated ozone exposure at } 150 \mathrm{ppb}+ \\
\text { foliar spray } 3 \% \text { Neem oil }\end{array}$ & $\begin{array}{l}0.41 \pm \\
0.095^{\text {dcba }}\end{array}$ & $\begin{array}{l}0.19 \pm \\
0.015^{b}\end{array}$ & $\begin{array}{l}0.09 \pm \\
0.034^{\mathrm{cb}}\end{array}$ & $\begin{array}{l}0.15 \pm \\
0.031^{b}\end{array}$ & $\begin{array}{l}0.11 \pm \\
0.020^{b}\end{array}$ \\
\hline $\begin{array}{l}\mathrm{T}_{9}-\text { Elevated ozone exposure at } 150 \mathrm{ppb}+ \\
\text { foliar spray } 0.1 \% \text { Ascorbic acid }\end{array}$ & $\begin{array}{l}0.41 \pm \\
0.030^{\text {dcba }}\end{array}$ & $\begin{array}{l}0.20 \pm \\
0.006^{b}\end{array}$ & $\begin{array}{l}0.14 \pm \\
0.042^{b}\end{array}$ & $\begin{array}{l}0.17 \pm \\
0.026^{b}\end{array}$ & $\begin{array}{l}0.13 \pm \\
0.031^{b}\end{array}$ \\
\hline $\begin{array}{l}\mathrm{T}_{10} \text { - Elevated ozone exposure at } 200 \mathrm{ppb}+ \\
\text { foliar spray } 3 \% \text { Panchagavya }\end{array}$ & $\begin{array}{l}0.54 \pm \\
0.058^{\mathrm{a}}\end{array}$ & $\begin{array}{l}0.15 \pm \\
0.023^{b}\end{array}$ & $\begin{array}{l}0.09 \pm \\
0.022^{\mathrm{cb}}\end{array}$ & $\begin{array}{l}0.11 \pm \\
0.017^{b}\end{array}$ & $\begin{array}{l}0.08 \pm \\
0.019^{b}\end{array}$ \\
\hline $\begin{array}{l}\mathrm{T}_{11}-\text { Elevated ozone exposure at } 200 \mathrm{ppb}+ \\
\text { foliar spray } 3 \% \text { Neem oil }\end{array}$ & $\begin{array}{l}0.51 \pm \\
0.036^{\mathrm{ba}}\end{array}$ & $\begin{array}{l}0.16 \pm \\
0.039^{b}\end{array}$ & $\begin{array}{l}0.08 \pm \\
0.012^{c b}\end{array}$ & $\begin{array}{l}0.14 \pm \\
0.026^{b}\end{array}$ & $\begin{array}{l}0.07 \pm \\
0.015^{b}\end{array}$ \\
\hline $\begin{array}{l}\mathrm{T}_{12} \text { - Elevated ozone exposure at } 200 \mathrm{ppb}+ \\
\text { foliar spray } 0.1 \% \text { Ascorbic acid }\end{array}$ & $\begin{array}{l}0.46 \pm \\
0.027^{\mathrm{cba}}\end{array}$ & $\begin{array}{l}0.18 \pm \\
0.030^{b}\end{array}$ & $\begin{array}{l}0.10 \pm \\
0.029^{c b}\end{array}$ & $\begin{array}{l}0.14 \pm \\
0.043^{b}\end{array}$ & $\begin{array}{l}0.09 \pm \\
0.020^{b}\end{array}$ \\
\hline$P$ value & 0.041 & 0.000 & 0.000 & 0.000 & 0.000 \\
\hline
\end{tabular}

(*DBE- Day before exposure, DAE- Day after exposure)

Table 2. Influence of tropospheric ozone on photosynthetic rate of garlic 


\begin{tabular}{|c|c|c|c|c|c|}
\hline Treatments & DBE & $1^{\text {st }} \mathrm{DAE}$ & $3^{\text {rd }}$ DAE & $5^{\text {th }} \mathrm{DAE}$ & $\begin{array}{l}7^{\text {th }} \\
\text { DAE }\end{array}$ \\
\hline $\mathrm{T}_{1}-$ Ambient ozone level & $\begin{array}{l}4.37 \pm \\
0.246\end{array}$ & $\begin{array}{l}4.25 \pm \\
0.697^{\text {ba }}\end{array}$ & $\begin{array}{l}3.65 \pm \\
1.108^{a}\end{array}$ & $\begin{array}{l}3.31 \pm \\
0.587^{\text {ba }}\end{array}$ & $\begin{array}{l}2.90 \pm \\
0.315^{a}\end{array}$ \\
\hline $\mathrm{T}_{2}-$ Elevated ozone exposure at $150 \mathrm{ppb}$ & $\begin{array}{l}4.41 \pm \\
0.164\end{array}$ & $\begin{array}{l}2.85 \pm \\
0.300^{\mathrm{cba}}\end{array}$ & $\begin{array}{l}2.39 \pm \\
0.579^{\text {ba }}\end{array}$ & $\begin{array}{l}1.42 \pm \\
0.236^{c}\end{array}$ & $\begin{array}{l}1.09 \pm \\
0.108^{b}\end{array}$ \\
\hline $\mathrm{T}_{3}-$ Elevated ozone exposure at $200 \mathrm{ppb}$ & $\begin{array}{l}4.14 \pm \\
0.332\end{array}$ & $\begin{array}{l}2.29 \pm \\
0.847^{c}\end{array}$ & $\begin{array}{l}1.66 \pm \\
0.254^{b}\end{array}$ & $\begin{array}{l}1.37 \pm \\
0.229^{c}\end{array}$ & $\begin{array}{l}0.82 \pm \\
0.127^{b}\end{array}$ \\
\hline $\begin{array}{l}\mathrm{T}_{4}-\text { Ambient Ozone level + foliar spray } 3 \% \\
\text { Panchagavya }\end{array}$ & $\begin{array}{l}4.68 \pm \\
0.159\end{array}$ & $\begin{array}{l}4.68 \pm \\
0.161^{\mathrm{a}}\end{array}$ & $\begin{array}{l}3.89 \pm \\
0.087^{a}\end{array}$ & $\begin{array}{l}3.96 \pm \\
0.072^{\mathrm{a}}\end{array}$ & $\begin{array}{l}3.02 \pm \\
0.360^{\mathrm{a}}\end{array}$ \\
\hline $\begin{array}{l}T_{5}-\text { Ambient Ozone level + foliar spray } 3 \% \\
\text { Neem oil }\end{array}$ & $\begin{array}{l}4.58 \pm \\
0.028\end{array}$ & $\begin{array}{l}4.25 \pm \\
0.286^{\mathrm{ba}}\end{array}$ & $\begin{array}{l}3.99 \pm \\
0.335^{\mathrm{a}}\end{array}$ & $\begin{array}{l}3.37 \pm \\
0.473^{\text {ba }}\end{array}$ & $\begin{array}{l}2.75 \pm \\
0.645^{a}\end{array}$ \\
\hline $\begin{array}{l}\mathrm{T}_{6}-\text { Ambient Ozone level + foliar spray } 0.1 \% \\
\text { Ascorbic acid }\end{array}$ & $\begin{array}{l}4.49 \pm \\
0.027\end{array}$ & $\begin{array}{l}4.62 \pm \\
1.257^{\mathrm{a}}\end{array}$ & $\begin{array}{l}3.80 \pm \\
0.783^{\mathrm{a}}\end{array}$ & $\begin{array}{l}3.89 \pm \\
0.369^{a}\end{array}$ & $\begin{array}{l}3.01 \pm \\
0.000^{\mathrm{a}}\end{array}$ \\
\hline $\begin{array}{l}\mathrm{T}_{7} \text { - Elevated ozone exposure at } 150 \mathrm{ppb}+ \\
\text { foliar spray } 3 \% \text { Panchagavya }\end{array}$ & $\begin{array}{l}4.75 \pm \\
0.437\end{array}$ & $\begin{array}{l}2.93 \pm \\
0.148^{\text {cba }}\end{array}$ & $\begin{array}{l}2.71 \pm \\
0.316^{\text {ba }}\end{array}$ & $\begin{array}{l}2.43 \pm \\
0.327^{\mathrm{cb}}\end{array}$ & $\begin{array}{l}1.40 \pm \\
0.281^{b}\end{array}$ \\
\hline $\begin{array}{l}\mathrm{T}_{8} \text { - Elevated ozone exposure at } 150 \mathrm{ppb}+ \\
\text { foliar spray } 3 \% \text { Neem oil }\end{array}$ & $\begin{array}{l}4.52 \pm \\
0.328\end{array}$ & $\begin{array}{l}2.84 \pm \\
0.087^{\mathrm{cba}}\end{array}$ & $\begin{array}{l}2.77 \pm \\
0.165^{\text {ba }}\end{array}$ & $\begin{array}{l}1.77 \pm \\
0.214^{c}\end{array}$ & $\begin{array}{l}1.19 \pm \\
0.187^{b}\end{array}$ \\
\hline $\begin{array}{l}\mathrm{T}_{9}-\text { Elevated ozone exposure at } 150 \mathrm{ppb}+ \\
\text { foliar spray } 0.1 \% \text { Ascorbic acid }\end{array}$ & $\begin{array}{l}4.69 \pm \\
0.318\end{array}$ & $\begin{array}{l}2.87 \pm \\
0.471^{\mathrm{cba}}\end{array}$ & $\begin{array}{l}2.71 \pm \\
0.353^{\mathrm{ba}}\end{array}$ & $\begin{array}{l}2.38 \pm \\
0.218^{\mathrm{cb}}\end{array}$ & $\begin{array}{l}1.32 \pm \\
0.344^{b}\end{array}$ \\
\hline $\begin{array}{l}\mathrm{T}_{10} \text { - Elevated ozone exposure at } 200 \mathrm{ppb}+ \\
\text { foliar spray } 3 \% \text { Panchagavya }\end{array}$ & $\begin{array}{l}4.44 \pm \\
0.184\end{array}$ & $\begin{array}{l}2.44 \pm \\
0.336^{\mathrm{cb}}\end{array}$ & $\begin{array}{l}1.89 \pm \\
0.360^{b}\end{array}$ & $\begin{array}{l}1.60 \pm \\
0.314^{c}\end{array}$ & $\begin{array}{l}0.98 \pm \\
0.087^{b}\end{array}$ \\
\hline $\begin{array}{l}T_{11} \text { - Elevated ozone exposure at } 200 \mathrm{ppb}+ \\
\text { foliar spray } 3 \% \text { Neem oil }\end{array}$ & $\begin{array}{l}4.33 \pm \\
0.081\end{array}$ & $\begin{array}{l}2.23 \pm \\
0.491^{c}\end{array}$ & $\begin{array}{l}1.76 \pm \\
0.575^{b}\end{array}$ & $\begin{array}{l}1.42 \pm \\
0.279^{c}\end{array}$ & $\begin{array}{l}0.86 \pm \\
0.099^{b}\end{array}$ \\
\hline $\begin{array}{l}\mathrm{T}_{12}-\text { Elevated ozone exposure at } 200 \mathrm{ppb}+ \\
\text { foliar spray } 0.1 \% \text { Ascorbic acid }\end{array}$ & $\begin{array}{l}4.37 \pm \\
0.142\end{array}$ & $\begin{array}{l}2.37 \pm \\
0.588^{\mathrm{cb}}\end{array}$ & $\begin{array}{l}1.92 \pm \\
0.416^{b}\end{array}$ & $\begin{array}{l}1.57 \pm \\
0.368^{\mathrm{c}}\end{array}$ & $\begin{array}{l}0.99 \pm \\
0.205^{b}\end{array}$ \\
\hline$P$ value & 0.860 & 0.019 & 0.015 & 0.000 & 0.000 \\
\hline
\end{tabular}

(*DBE- Day before exposure, DAE- Day after exposure)

\section{Figures}




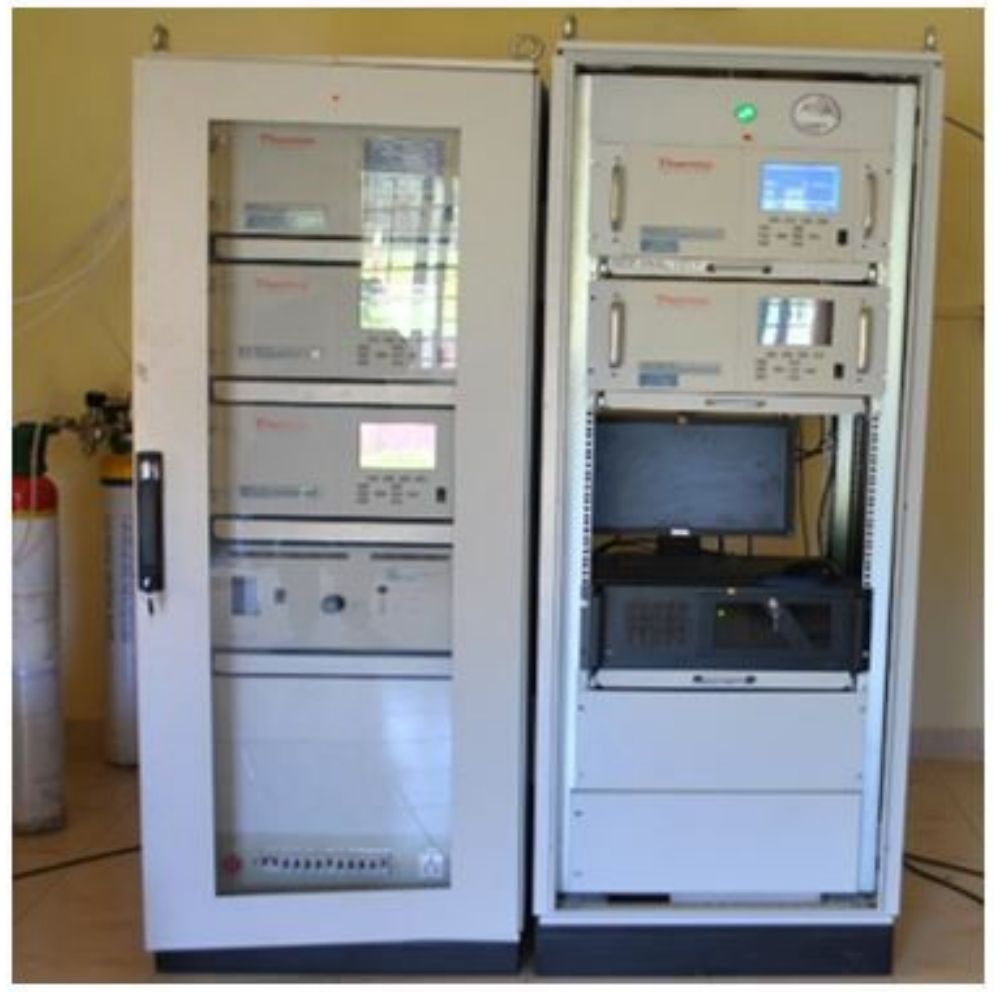

Figure 1

Thermo Fischer U.S.A Model 49i - measuring ambient 03 levels 


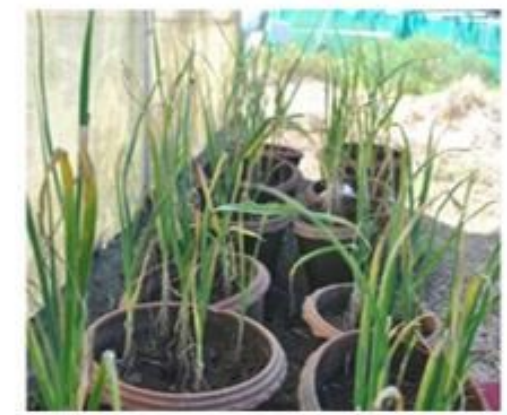

(6)

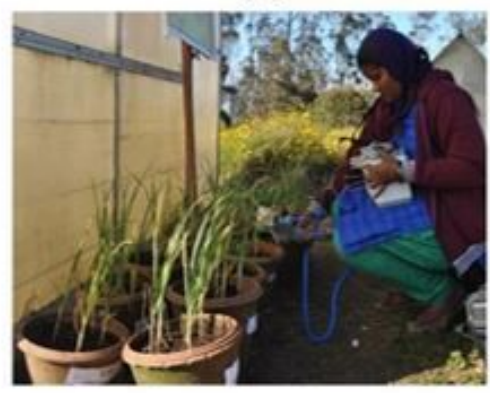

(5)

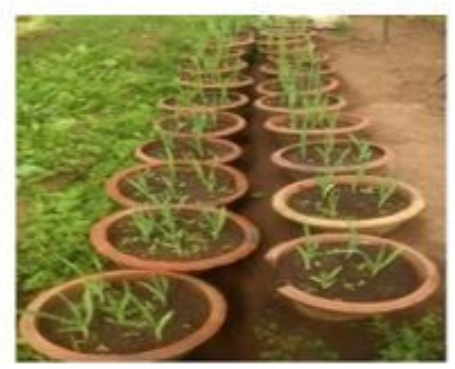

(1)

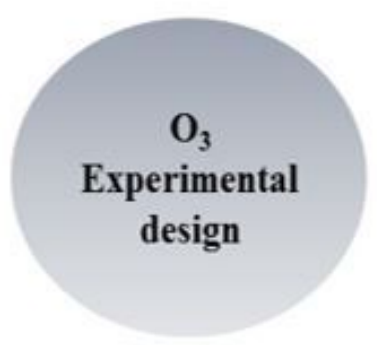

(4)

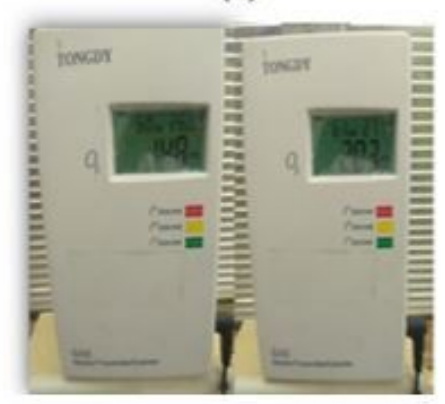

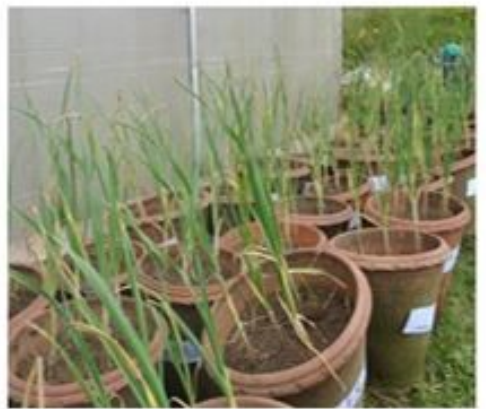

(2)

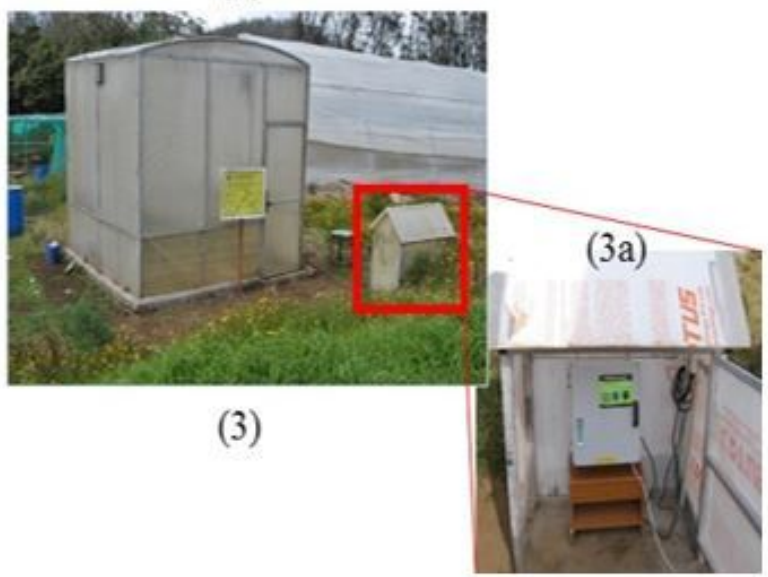

\section{Figure 2}

O3 Experimental design: 1) Potted garlic seedlings, 2) Garlic plants at critical stage i.e., bulb initiation stage, 3) Open top chamber- within which the potted plants were exposed to elevated levels of 03, 3a) Ozone Generator - fixed to the ground surface for stimulating elevated levels of ozone, 4) Ozone monitorfixed inside the OTC for monitoring the 03 elevated levels (150ppb and 200ppb), 5) Measurement of photosynthetic rate, stomatal conductance using Portable photosynthetic system and chlorophyll content by using chlorophyll content meter, 6 ) Potted garlic plants after exposure to elevated levels of 03 


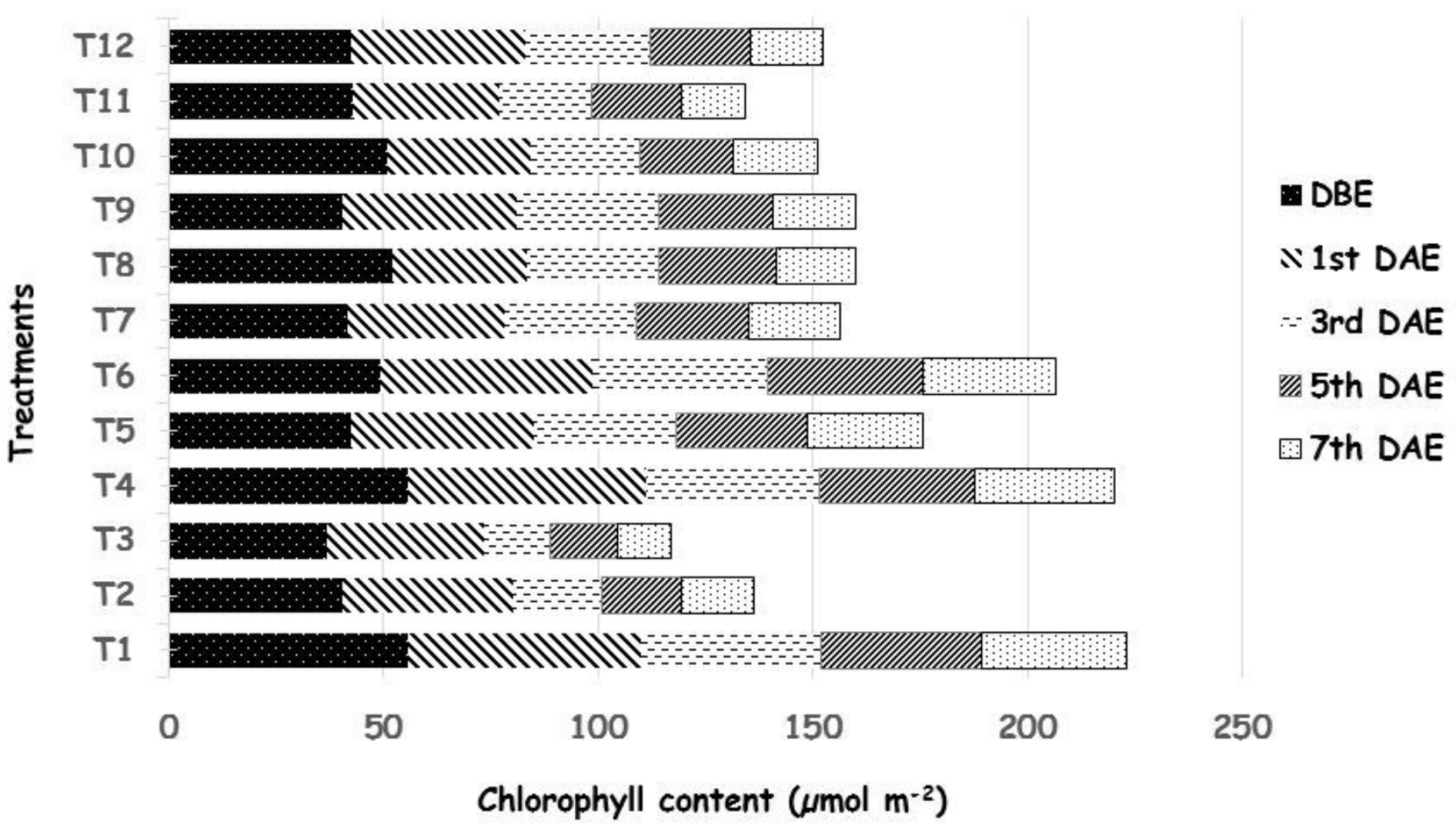

Figure 3

Influence of tropospheric ozone on chlorophyll content of garlic

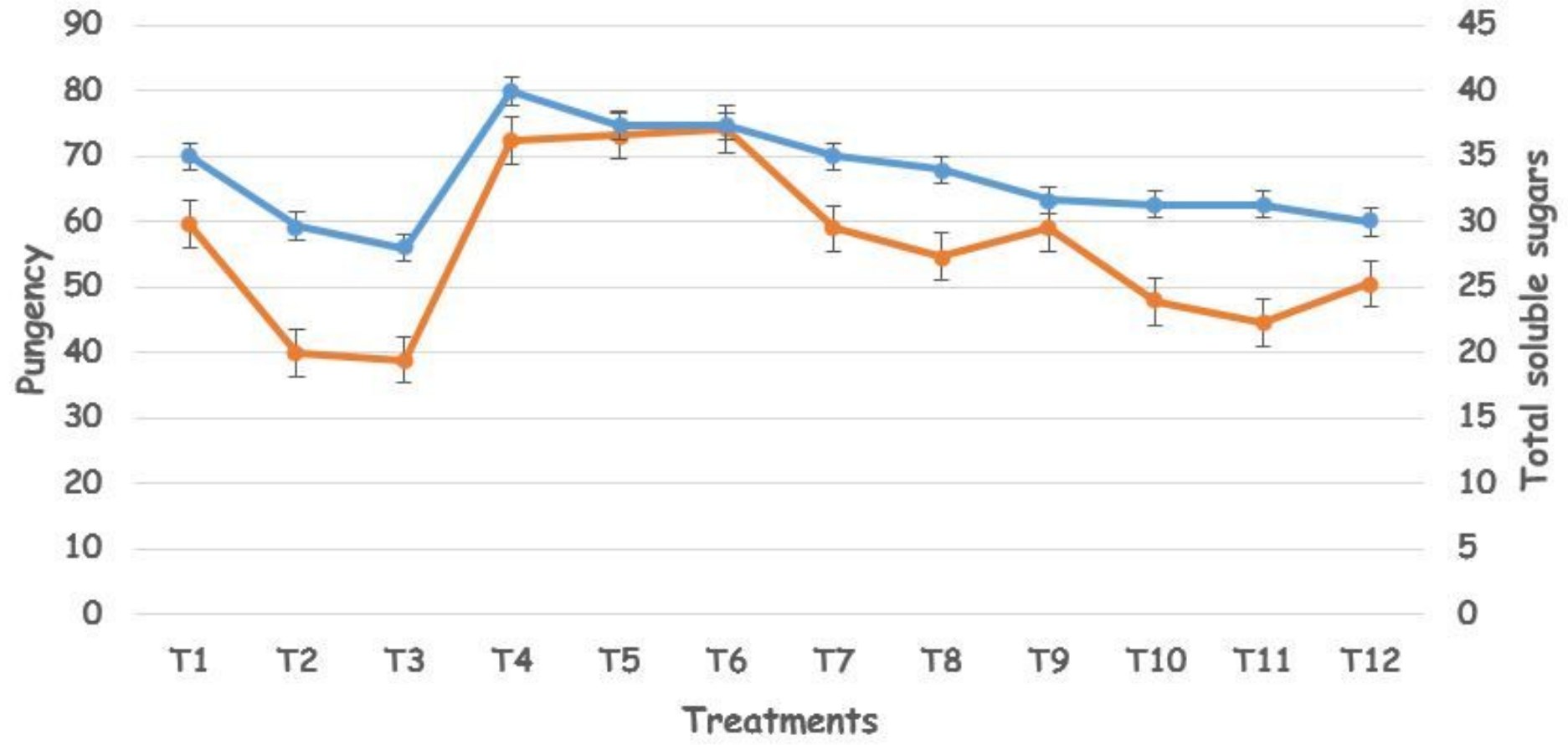

Figure 4 
Effect of tropospheric ozone on quality parameters of Garlic - Pungency ( $\mu \mathrm{mol} \mathrm{g}^{\mathrm{TM}}$ ) and Total Soluble Sugars ( ${ }^{\circ}$ Brix) where Orange line indicates the pungency and Blue line indicates TSS ( ${ }^{\circ}$ Brix).

\section{Supplementary Files}

This is a list of supplementary files associated with this preprint. Click to download.

- GraphicalAbstract.jpg 